\title{
RENTABILITAS BANK UMUM SYARIAH SESUDAH SPIN-OFF BERDASARKAN TIPE PEMISAHANNYA DI INDONESIA
}

\author{
Ratna Maya Sari \\ Politeknik Negeri Bandung \\ ratnamaya25@gmail.com
}

\begin{abstract}
Abstrak : Dalam penelitian ini akan dilakukan pembahasan terhadap 2 alternatif tipe pemisahan unit usaha syariah menjadi bank umum syariah, yaitu tipe pemisahan murni dan tidak murni, dengan mengambil studi kasus pada PT. Bank BNI Syariah, PT. Bank BJB Syariah, PT. Bank BRI Syariah dan PT. Bank BUKOPIN Syariah. Penelitian ini bersifat deskriptif dan proses analisis data akan dilakukan melalui beberapa tahap yaitu pengolahan data berdasarkan rasio rentabilitas (ROA, NOM dan NI), kemudian akan dilakukan uji menggunakan SPSS yaitu uji normalitas dan selanjutnya dilakukan uji beda menggunakan metode Mann-Whitney U Test. Hasil dari penelitian ini menunjukkan bahwa baik tipe pemisahan murni maupun tipe pemisahan tidak murni memiliki kualitas yang sama dalam hal produktivitas terhadap aset yang dimiliki, sehingga bank umum konvensional tidak perlu menghawatirkan pemilihan metode mana yang lebih baik diantara kedua tipe pemisahan (spin-off) yang tersedia.
\end{abstract}

Kata kunci: Bank Umum Syariah, rentabilitas, spin-off

\begin{abstract}
This research will be discussed on two alternative types of separation of sharia business unit into a sharia commercial bank, the type of pure and impure separation, by taking case studies at PT. Bank BNI Syariah, PT. Bank BJB Syariah, PT. Bank BRI Syariah and PT. Bank BUKOPIN Syariah. This research is a descriptive research. The process of data analysis will be done through several stages there are data processing based on rentability ratio (ROA, NOM and NI), then will be tested using SPSS that is normality test and then do the different test using Mann-Whitney U Test method. The results of this study indicate that both pure separation or impure separation types have the same quality in terms of productivity of assets owned, so conventional commercial banks do not have to worry about the choice of which method is better between the two types of spin-off that available.
\end{abstract}

Keywords: Islamic Commercial Bank, rentability, spin-off

\section{PENDAHULUAN}

Perihal penting yang diatur dalam Pasal 68 ayat 1 Undang-undang Perbankan Syariah Nomor 21 tahun 2008 yaitu mengenai pemisahan unit usaha syariah menjadi bank umum syariah. Dijelaskan jika Bank Umum Konvensional (BUK) memiliki Unit Usaha Syariah (UUS) yang nilai asetnya telah mencapai paling sedikit $50 \%$ dari total nilai aset bank induknya atau 15 tahun sejak berlakunya UndangUndang ini, maka BUK dimaksud wajib melakukan Pemisahan UUS tersebut menjadi Bank Umum Syariah (BUS). Terlihat secara umum dari pasal tersebut bahwa spin-off UUS wajib setelah memenuhi salah satu dari persyaratan yang ditentukan, sekaligus mempertegas bahwa keberadaan UUS sejak semula bersifat sementara. Spin-off UUS menjadi BUS yang belum memenuhi keterangan pada pasal 68 ayat 1 dapat dilakukan dengan terlebih dahulu mendapat izin dari Bank Indonesia. 
Menurut Rahma, Rifin dan Saptono (2015), fenomena spin-off menjadi alternatif strategi yang dipilih oleh berbagai perusahaan, mengingat pelaksanaan startegi tersebut terbukti memberikan dampak yang positif bagi kinerja perusahaan. Beberapa praktisi perbankan berpendapat bahwa dengan adanya spin-off, perbankan syariah di Indonesia dapat lebih berkembang. BUS baru yang terbentuk dari hasil spin-off dapat mengatur dan mengelola keuangan secara independen sehingga dapat semakin fokus dalam beroperasi, cepat dan fleksibel dalam pengambilan keputusankeputusan bisnis, serta kebijakan untuk perbaikan perusahaan dapat dilakukan lebih tepat guna. Sedangkan dilihat dari sisi ketaatan syariah, spin-off merupakan upaya menjadikan Bank Umum Syariah yang lebih murni menjalankan kegiatan operasinya berdasarkan prinsip syariah dengan pembatasan yang jelas antara unit syariah dengan bank konvensional sehingga usaha syariah tidak tercampur dengan usaha BUK yang dilarang dalam prinsip islam. Dengan demikian BUS dapat leluasa menjalankan kebijakan yang telah dibentuk berdasarkan prinsip syariah.

Terdapat dua tipe pemisahan unit usaha syariah yang dapat dilakukan sesuai dengan Peraturan Bank Indonesia, yaitu: pertama, mendirikan badan hukum yang baru, dimana pada pendekatan ini bank umum konvensional melakukan pemisahan atas UUS yang dimiliki, kemudian UUS tersebut dijadikan Bank Umum Syariah (BUS) tersendiri. Tipe pemisahan ini dikenal sebagai tipe pemisahan murni. Kedua, menggunakan badan hukum yang sudah ada, dimana pada pendekatan ini bank umum konvensional yang memiliki UUS mengakuisisi bank yang relatif kecil kemudian mengkonversinya menjadi bank umum syariah, selanjutnya bank umum konvensional yang memiliki unit usaha syariah tersebut memisahkan dan menggabungkan UUS-nya dengan bank yang baru dikonversi menjadi BUS. Tipe pemisahan ini biasa disebut tipe pemisahan tidak murni.

Keputusan pemilihan tipe pemisahan (spin-off) ditentukan berdasarkan kebijakan yang diambil oleh Bank Umum Konvensional yang memiliki UUS itu sendiri. Bank umum konvensional harus mempertimbangkan berbagai faktor penting yang dapat memberikan kondisi terbaik bagi perkembangan usaha kedepannya. Di Indonesia, sejak tahun 2008 hingga tahun 2015 terdapat 5 Bank Umum Syariah hasil pemisahan Unit Usaha Syariah BUK. Terdapat 2 Bank Umum Syariah yang melakukan pemisahan (spin-off) dengan tipe pemisahan murni. Sedangkan untuk tipe 
pemisahan tidak murni ada 3 Bank Umum Syariah.

Spin-off merupakan salah satu upaya yang dapat dilakukan Bank Umum Syariah untuk memastikan stabilitas usaha serta memperbaiki dan memaksimalkan laba perusahaan, mengingat pemaksimalan laba merupakan salah satu tujuan utama setiap perusahaan. Laba merupakan hal penting yang harus dicapai oleh setiap perusahaan karena laba mampu mencerminkan kemampuan perusahaan dalam melakukan produktivitas terhadap aset yang dimiliki. Laba perusahaan dapat diukur dengan menganalisisa dan mengevaluasi laporan keuangan. Alat ukur yang digunakan untuk menganalisis laporan keuangan yang dapat menunjukkan kondisi laba perusahaan adalah adalah rasio rentabilitas. Adapun pengukuran laba dengan menggunakan rasio rentabilitas berlandaskan pada Surat Edaran Otoritas Jasa Keuangan (SEOJK) Nomor 10/SEOJK.03/2014 tentang Penilaian Tingkat Kesehatan Bank Umum Syariah dan Unit Usaha Syariah, dimana rasio rentabilitas yang dapat dijadikan indikator pengukuran yaitu Return On Asset (ROA), Net Operation Margin (NOM) dan Net Imbalan (NI).

\section{KAJIAN PUSTAKA}

\section{Rentabilitas}

Pengukuran kinerja berdasarkan rentabilitas dapat diartikan sebagai salah satu cara mengukur efektivitas perusahaan dalam memperoleh laba. Kemampuan perusahaan dalam menghasilkan laba dapat diukur menggunakan indikator dari beberapa rasio-rasio. Berdasarkan Peraturan Otoritas Jasa Keuangan (POJK) Nomor 8/POJK.03/2014 tentang PenilaianTingkat Kesehatan Bank Umum Syariah dan Unit Usaha Syariah dan dijabarkan lebih jelas pada Surat Edaran Otoritas Jasa Keuangan (SEOJK) Nomor 10/SEOJK.03/2014 tentang Penilaian Tingkat Kesehatan Bank Umum Syariah dan Unit Usaha Syariah terdapat beberapa rasio dalam mengukur kinerja rentabilitas. Rasio-rasio tersebut Return on Assets (ROA), Net Operation Margin (NOM), Net Imbalan (NI)

\section{ROA (Return On Asset)}

Return on Asset (ROA) adalah salah satu bentuk dari rasio profitabilitas untuk mengukur kemampuan perusahaan dalam menghasilkan laba dengan menggunakan total aktiva yang ada dan setelah biayabiaya modal (biaya yang digunakan mendanai aktiva) dikeluarkan dari analisis (Mulya, 2011). ROA adalah gambaran produktivitas bank dalam mengelola dana sehingga menghasilkan keuntungan. Penentuan ROA dilakukan dengan membagi antara laba sebelum pajak dengan rata-rata total asetnya. 
Menurut Surat Edaran Otoritas Jasa Keuangan (SEOJK) Nomor 10/SEOJK.03/2014 tentang Penilaian Tingkat Kesehatan Bank Umum Syariah dan Unit Usaha Syariah, ROA didapatkan dengan rumus:

$$
R O A=\frac{\text { laba sebelum pajak }}{\text { rata }- \text { rata total aset }}
$$

\section{NOM (Net Operation Margin)}

Umumnya, rasio yang digunakan untuk menunjukkan kemampuan perusahaan dalam menghasilkan keuntungan bunga bersih pada bank konvensiaonal adalah Net Interest Margin

(NIM). Akan tetapi, bank syariah menjalankan kegiatan operasional bank tidak dengan sistem bunga, maka dalam penilaian rasio NIM pada bank syariah menggunakan rasio Net Operating Margin (NOM) yang merupakan pendapatan penyaluran dana setelah bagi hasil dikurangi dengan beban operasional terhadap rata-rata aktiva produktif.

Menurut Surat Edaran Otoritas Jasa Keuangan (SEOJK) Nomor 10/SEOJK.03/2014 tentang Penilaian Tingkat Kesehatan Bank Umum Syariah dan Unit Usaha Syariah, NOM didapatkan dengan rumus:

$$
N O M=\frac{(\text { Pendapatan penyaluran dana setelah bagi hasil }- \text { beban operasional })}{\text { rata }- \text { rata aktiva produktif }}
$$

\section{Net Imbalan (NI)}

Rasio Net Imbalan dapat diperoleh dengan membagi pendapatan penyaluran dana setelah bagi hasil dikurangi (imbalan dan bonus) terhadap rata-rata total aktiva produktif. Pendapatan Penyaluran Dana Setelah Bagi Hasil - (Imbalan dan Bonus) adalah pendapatan penyaluran dana setelah dikurangi beban imbal hasil, imbalan, dan bonus (disetahunkan). Pendapatan penyaluran dana meliputi seluruh pendapatan dari penyaluran dana, sedangkan beban imbal hasil meliputi

$$
N I=\frac{\text { (Pendapatan penyaluran dana setelah bagi hasil }-(\text { imbalan dan bonus })}{\text { rata }- \text { rata aktiva produktif }}
$$

seluruh beban bagi hasil, imbalan, dan bonus dari penghimpunan dana.

Aktiva produktif yang diperhitungkan adalah aset yang menghasilkan bagi hasil, imbalan, dan bonus baik di neraca maupun pada TRA (Transaksi Rekening Administratif) rata-rata aktiva produktif. Menurut Surat Edaran Otoritas Jasa Keuangan (SEOJK) Nomor 10/SEOJK.03/2014 tentang Penilaian Tingkat Kesehatan Bank Umum Syariah dan Unit Usaha Syariah, NI didapatkan dengan rumus: 
Pemisahan atau Spin-Off Bank Syariah

Pemisahan (spin-off) adalah pemisahan usaha dari satu BUK menjadi dua badan usaha atau lebih sesuai dengan ketentuan peraturan perundang-undangan yang berlaku. Tujuan pemisahan (spin-off) unit usaha syariah dari bank umum konvensional-nya menjadi bank umum syariah adalah agar BUS yang baru terbentuk tersebut dapat mengatur dan mengelola keuangan secara independen sehingga dapat semakin fokus dalam beroperasi, cepat dan fleksibel dalam pengambilan keputusan-keputusan bisnis, serta kebijakan untuk perbaikan bank syariah dapat dilakukan lebih tepat guna.

Spin-off unit usaha syariah menjadi bank umum syariah diatur dalam PBI Nomor 11/10/PBI/2009 tentang unit usaha syariah. PBI ini memberikan penjelasan ketentuan lebih lanjut mengenai spin-off dan sanksi bagi bank umum konvensional yang tidak melakukan spin-off sebagaimana dimaksud pada UU No. 21 tahun 2008 diatas. Ketentuan mengenai modal disetor minimal yang harus dipenuhi serta keterangan lain mengenai metode spin-off unit usaha syariah milik bank umum konvensional secara rinci dijelaskan pada pasal 45 hingga pasal 54 PBI Nomor 11/10/PBI/2009.

\section{Tipe Pemisahan (Spin-off)}

Bank umum konvensional yang akan melakukan pemisahan (spin-off) harus memiliki unit usaha syariah. Berdasarkan penjelasan dalam PBI Nomor 11/10/PBI/2009, terdapat dua tipe spin-off unit usaha syariah yang dapat dilakukan BUK, yaitu: pertama, mendirikan badan hukum yang baru, dimana pada pendekatan ini bank umum konvensional melakukan pemisahan atas UUS yang dimiliki, kemudian UUS tersebut dijadikan Bank Umum Syariah (BUS) tersendiri. Tipe spin-off ini dikenal sebagai pemisahan murni. Kedua, menggunakan badan hukum yang sudah ada, dimana pada pendekatan ini bank umum konvensional yang memiliki UUS mengakuisisi bank yang relatif kecil kemudian mengkonversinya menjadi bank umum syariah, selanjutnya bank umum konvensional yang memiliki unit usaha syariah tersebut memisahkan dan menggabungkan UUS-nya dengan bank yang baru dikonversi menjadi BUS. Tipe spin-off ini biasa disebut pemisahan tidak murni.

\section{METODE PENELITIAN}

Penelitian ini menggunakan metode deskriptif komparatif karena penelitian ini bersifat membandingkan beberapa variabel dari sampel yang berbeda. Penelitian deskriptif adalah suatu metode penelitian yang menggambarkan semua data atau keadaan subjek/objek penelitian kemudian dianalisis dan dibandingkan berdasarkan 
kenyataan yang sedang berlangsung saat ini dan selanjutnya mencoba untuk memberikan pemecahan masalahnya (Widi dalam Ramadhan, 2015). Metode ini digunakan untuk menjelaskan hasil perbandingan kinerja bank umum syariah 3 tahun setelah spin-off berdasarkan tipe pemisahannya. Sedangkan penelitian komparatif digunakan untuk membandingkan rasio rentabilitas dari masing-masing tipe pemisahan (spin-off).

Sedangkan teknis analisis data yang digunakan terdiri atas dua tahapan, yaitu:

a. Pengukuran kinerja berdasarkan rentabilitas.

Langkah pertama yang dilakukan adalah menghitung rata-rata perperiode dari laporan tahunan masing-masing bank menggunakan rumus yang telah ditetapkan berdasarkan Surat Edaran Otoritas Jasa Keuangan (SEOJK) Nomor 10/SEOJK.03/2014 tentang Penilaian Tingkat Kesehatan Bank Umum Syariah dan Unit Usaha Syariah

b. Pembandingan kinerja menggunakan teknik uji beda.

Membandingkan dari hasil rata-rata perperiode masing-masing rasio antara tipe pemisahan murni terhadap tipe pemisahan tidak murni. Adapun tahapan pembandingan tersebut sebagai berikut:
- Uji Normalitas Data

Uji nomalitas data dilakukan dengan menggunakan Shapiro-wilk untuk melihat apakah data terdistribusi secaranormal atau tidak. Apabila nilai signifikannya lebih dari 0,05 maka data yang terdistribusi normal, namun apabila nilai signifikannya kurang dari 0,05 maka data yang terdistribusi tidak normal. Jika data terdistribusi normal, pengujian hipotesis menggunakan paired sample t-test, sedangkan data yang tidak terdistribusi normal, pengujian hipotesis menggunakan uji data tidak berpasangan Mann Whitney U Test.

- Uji Hipotesis.

Data yang terdistribusi normal bisa menggunakan menggunakan Independent sample test t-test. Independent sample t-test digunakan untuk melakukan pengujian pada dua variabel apabila sampel yang diuji adalah berbeda dan perlakuan yang diberikan juga berbeda.

\section{PEMBAHASAN}

Uji Normalitas Data Kinerja Keuangan Berdasarkan Rentabilitas

Uji normalitas dari output yang dihasilkan program SPSS 18 terdapat empat uji analisis normalitas data, yaitu Kolmogorov Smirnov, Shapiro-wilk, 
Ratna Maya Sari : Rentabilitas Bank Umum Syariah..

Normal Q-Q Plots dan Detrended normal $Q-Q$ Plots. Untuk uji normalitas, penulis mengacu pada analisis Shapiro-wilk karena metode ini merupakan metode normalitas yang efektif dan valid digunakan untuk sampel berjumlah kecil. Selain itu dikarenakan data variabel independen yang digunakan dalam penelitian bukan merupakan data kuantitatif melainkan kualitatif.

Berikut adalah hasil uji normalitas dari data-data penelitian yang telah diperoleh dari tiap-tiap kelompok sampel penelitian:

\begin{tabular}{|c|c|c|c|c|c|c|c|}
\hline & \multirow[t]{2}{*}{ Kelompok } & \multicolumn{3}{|c|}{ Kolmogorov-Smirnov ${ }^{\mathrm{a}}$} & \multicolumn{3}{|c|}{ Shapiro-Wilk } \\
\hline & & Statistic & df & Sig. & Statistic & df & Sig. \\
\hline \multirow[t]{3}{*}{ Bank_ROA } & MURNI &, 224 & 6 & $200^{\circ}$ & ,929 & 6 &, 575 \\
\hline & TIDAK & ,402 & 6 & ,003 &, 588 & 6 &, 000 \\
\hline & MURNI & & & & & & \\
\hline \multirow[t]{3}{*}{ Bank_NOM } & MURNI & ,203 & 6 & $200^{\circ}$ & 899 & 6 &, 365 \\
\hline & TIDAK & 277 & 6 & , 167 &, 872 & 6 &, 233 \\
\hline & MURNI & & & & & & \\
\hline \multirow[t]{3}{*}{ Bank_NI } & MURNI & ,187 & 6 &, $200^{\circ}$ & ,928 & 6 &, 567 \\
\hline & TIDAK & 140 & 6 &, $200^{\circ}$ & ,969 & 6 &, 884 \\
\hline & MURNI & & & & & & \\
\hline
\end{tabular}

a. Lilliefors Significance Correction

*. This is a lower bound of the true significance.

Sumber: hasil olahan SPSS

Tabel 1. Hasil Uji Normalitas Shapiro-Wilk

Dari tabel 1 diatas diperoleh hasil bahwa nilai probabilitas (Sig.) ROA untuk kelompok bank tipe pemisahan murni adalah 0,575 lebih besar dari 0,05, sedangkan nilai probabilitas (Sig.) ROA untuk kelompok bank tipe pemisahan tidak murni adalah 0,000 lebih kecil dari 0,05. Berdasarkan hasil analisis data tersebut, dapat disimpulkan bahwa data tes kinerja keuangan berdasarkan ROA (Return On Asset) bank umum syariah tipe pemisahan murni berada pada taraf distribusi Normal.
Berbeda dengan hasil analisis data tes kinerja keuangan berdasarkan ROA (Return On Asset) bank umum syariah tipe pemisahan tidak murni berada pada taraf distribusi Tidak Normal.

NOM untuk kelompok bank tipe pemisahan murni adalah 0,365 lebih besar dari 0,05 , sedangkan nilai probabilitas (Sig.) NOM untuk kelompok bank tipe pemisahan tidak murni adalah 0,233 lebih besar dari 0,05. Berdasarkan hasil analisis data tersebut, dapat disimpulkan bahwa 
data tes kinerja keuangan berdasarkan NOM (Net Operating Margin) bank umum syariah baik tipe pemisahan murni maupun tipe pemisahan tidak murni berada pada taraf distribusi Normal. Dengan demikian dapat dinyatakan bahwa pengujian statistik normalitas data tes NOM (Net Operating Margin) pada kedua jenis tipe pemisahan telah terpenuhi.

NI untuk kelompok bank tipe pemisahan murni adalah 0,567 lebih besar dari 0,05 , sedangkan nilai probabilitas (Sig.) NOM untuk kelompok bank tipe pemisahan tidak murni adalah 0,884 lebih besar dari 0,05. Berdasarkan hasil analisis data tersebut, dapat disimpulkan bahwa data tes kinerja keuangan berdasarkan NI
(Net Imbalan) bank umum syariah baik tipe pemisahan murni maupun tipe pemisahan tidak murni berada pada taraf distribusi Normal. Dengan demikian dapat dinyatakan bahwa pengujian statistik normalitas data tes NI (Net Imbalan) pada kedua jenis tipe pemisahan telah terpenuhi.

\section{Uji Mann Whitney U Test}

Analisis Uji Mann Whitney ROA tipe pemisahan murni dan tidak murni dapat dilihat pada tabel di bawah yang didalamnya terdapat Tabel Descriptive Statistic, Tabel Ranks serta Tabel Test Statistics. Berikut data hasil uji MannWhitney U Test ROA pada bank umum syariah hasil spin-off berdasarkan tipe pemisahannya:

\begin{tabular}{|l|r|r|r|r|r|}
\hline & $\mathrm{N}$ & \multicolumn{1}{|c|}{ Descriptive Statistics } \\
\hline Kinerja_ROA & 12 &,- 01059328 & Std. Deviation & Minimum & \multicolumn{1}{c|}{ Maximum } \\
TIpe & 12 &, 051147774 &,- 171288 &, 012939 \\
\hline
\end{tabular}

Sumber: hasil olahan SPSS

Tabel 2. Hasil Uji Descriptive Statistic Mann-Whitney

\section{ROA Tipe Pemisahan Murni dan Tidak Murni}

Dari tabel 2 Descriptive Statistic diatas, diperoleh informasi bahwa dari keseluruhan data pada kinerja ROA yaitu sebanyak 12 sampel, nilai rata-rata (mean) yang diperoleh adalah sebesar -,01059328. Dari hasil uji nilai rata-rata ini diketahui bahwa dari 12 sampel data ROA, terdapat 2 data yang berada di bawah nilai rata-rata, yaitu Bank BRI Syariah pada tahun 2008 dan Bank Bukopin Syariah pada tahun 2008 


\begin{tabular}{|ll|r|r|r|}
\hline \multicolumn{5}{|c|}{ Ranks } \\
\hline Tinerja_ROA & N & Mean Rank & Sum of Ranks \\
& Murni & 6 & 9,00 & 54,00 \\
& Tidak Murni & 6 & 4,00 & 24,00 \\
& Total & 12 & & \\
\hline
\end{tabular}

Sumber: hasil olahan SPSS

Tabel 3. Hasil Uji Ranks Mann-Whitney ROA

Tipe Pemisahan Murni dan Tidak Murni

Dari tabel 3 Ranks diatas, diperoleh informasi bahwa terdapat dua kelompok dengan tipe pemisahan yang berbeda. Pertama, bank umum syariah hasil pemisahan (Spin-Off) dengan tipe pemisahan murni. Kedua, bank umum syariah hasil pemisahan (Spin-Off) dengan tipe pemisahan tidak murni. Dari tabel ini juga menunjukkan Mean Rank atau ratarata ROA tiap tipe pemisahan. Pada tipe murni rata-rata ROA 9,00 lebih besar daripada rata-rata tipe tidak murni, yaitu 4,00 .

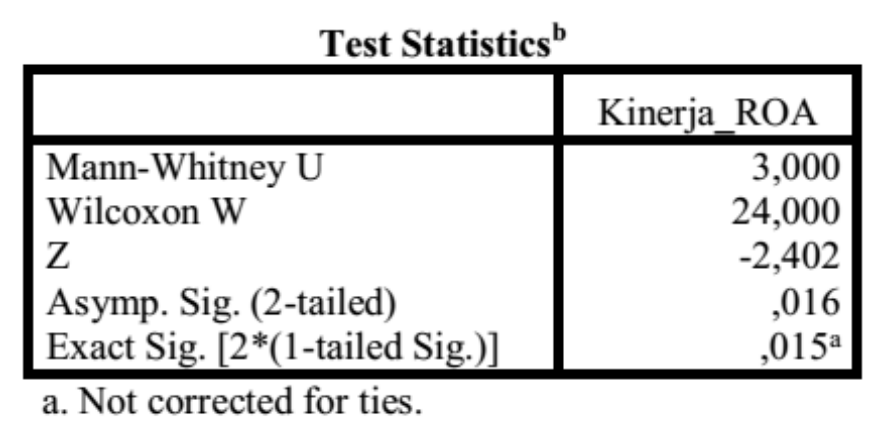
a. Not corrected for ties.
b. Grouping Variable: TIpe

Sumber: hasil olahan SPSS

Tabel 4. Hasil Uji Test Statistic Mann-Whitney ROA

Tipe Pemisahan Murni dan Tidak Murni

Dari tabel 4 Test Statistics diatas, diperoleh informasi bahwa nilai Asymp. Sig. (2-tailed) yaitu 0,016 lebih kecil dari 0,05. Hal ini menyatakan bahwa Ho ditolak. Dengan diterimanya $\mathrm{Ha}$ maka dapat disimpulkan bahwa terdapat perbedaan ROA secara signifikan antara tipe pemisahan murni dan tipe pemisahan tidak murni. 
Hasil Uji Mann Whitney NOM (Net Operating Margin) Tipe Pemisahan Murni dan Tipe Pemisahan Tidak Murni

Analisis Uji Mann Whitney NOM tipe pemisahan murni dan tidak murni dapat dilihat pada tabel IV.8, IV.9 dan IV.10, yang didalamnya terdapat Tabel Descriptive Statistic, Tabel Ranks serta Tabel Test Statistics. Berikut data hasil uji Mann-Whitney U Test NOM pada bank umum syariah hasil pemisahan (spin-off) berdasarkan tipe pemisahannya:

\begin{tabular}{|l|r|c|r|r|r|}
\hline & \multicolumn{1}{|c|}{ Descriptive Statistics } \\
\hline Kinerja_NOM & N & Mean & Std. Deviation & Minimum & Maximum \\
Tlpe & 12 &, 04647547 &, 015151054 &, 027943 &, 070810 \\
12 & 1,50 &, 522 & 1 & 2 \\
\hline
\end{tabular}

Sumber: hasil olahan SPSS

Tabel 5. Hasil Uji Descriptive Statistic Mann Whitney NOM Tipe Pemisahan Murni dan Tidak Murni

Dari tabel 5 Descriptive Statistic diatas, diperoleh informasi bahwa dari keseluruhan data pada kinerja NOM yaitu sebanyak 12 sampel, nilai rata-rata (mean) yang diperoleh adalah sebesar 0,04647547. Dari hasil uji nilai rata-rata ini diketahui bahwa dari 12 sampel data NOM, terdapat 7 data yang berada di bawah nilai rata-rata, ketujuh nilai rata-rata ini berasal dari bank umum syariah tipe pemisahan murni maupun tipe pemisahan tidak murni.

\begin{tabular}{|ll|r|r|r|}
\hline \multicolumn{5}{|c|}{ Ranks } \\
\hline Tinerja_NOM & N & Mean Rank & Sum of Ranks \\
& Murni & 6 & 7,17 & 43,00 \\
& Tidak Murni & 6 & 5,83 & 35,00 \\
& Total & 12 & & \\
\hline
\end{tabular}

Sumber: hasil olahan SPSS

\section{Tabel 6. Hasil Uji Ranks Mann Whitney NOM}

\section{Tipe Pemisahan Murni dan Tidak Murni}

Dari tabel 6 Ranks diatas, diperoleh informasi bahwa terdapat dua kelompok dengan tipe pemisahan yang berbeda. Pertama, bank umum syariah hasil pemisahan (Spin-Off) dengan tipe pemisahan murni. Kedua, bank umum syariah hasil pemisahan (Spin-Off) dengan tipe pemisahan tidak murni. Dari tabel ini juga menunjukkan Mean Rank atau ratarata NOM tiap tipe pemisahan. Pada tipe 
murni rata-rata NOM 7,17 lebih besar daripada rata-rata tipe tidak murni, yaitu 5,83. Dari hasil uji ini, dapat disimpulkan bahwa perbedaan rata-rata NOM antara kedua tipe pemisahan hanya sebesar 1,34.

\begin{tabular}{|l|r|}
\hline \multicolumn{2}{|c|}{ Test Statistics $^{\mathbf{b}}$} \\
\hline Mann-Whitney U & Kinerja_NOM \\
Wilcoxon W & 14,000 \\
Z & 35,000 \\
Asymp. Sig. (2-tailed) &,- 641 \\
Exact Sig. [2*(1-tailed Sig.)] &, 522 \\
\hline
\end{tabular}

a. Not corrected for ties.

b. Grouping Variable: Tipe

Sumber: hasil olahan SPSS

\section{Tabel 7. Hasil Uji Test Statistics Mann Whitney NOM}

Tipe Pemisahan Murni dan Tidak Murni

Dari tabel 7 Test Statistics diatas, diperoleh informasi bahwa nilai Asymp. Sig. (2-tailed) yaitu 0,522 lebih besar dari 0,05. Hal ini menyatakan bahwa Ho diterima. Dengan ditolaknya $\mathrm{Ha}$ maka dapat disimpulkan bahwa tidak terdapat perbedaan NOM secara signifikan antara tipe pemisahan murni dan tipe pemisahan tidak murni.
Hasil Uji Mann Whitney NI (Net Imbalan) Tipe Pemisahan Murni dan Tipe Pemisahan Tidak Murni

Analisis Uji Mann Whitney NI tipe pemisahan murni dan tidak murni dapat dilihat pada tabel di bawah yang didalamnya terdapat Tabel Descriptive Statistic, Tabel Ranks serta Tabel Test Statistics. Berikut data hasil uji MannWhitney U Test NI pada bank umum syariah hasil pemisahan (spin-off ) berdasarkan tipe pemisahannya:

Descriptive Statistics

\begin{tabular}{|l|r|c|r|r|r|}
\hline & $\mathrm{N}$ & Mean & Std. Deviation & Minimum & Maximum \\
\hline Kinerja_NI & 12 &, 06781606 &, 015236465 &, 040450 &, 090382 \\
TIpe & 12 & 1,50 &, 522 & 1 & 2 \\
\hline
\end{tabular}

Sumber: hasil olahan SPSS

Tabel 8. Hasil Uji Descriptive Statistics Mann Whitney NI

Tipe Pemisahan Murni dan Tidak Murni 

Dari tabel 8 Descriptive Statistic diatas, diperoleh informasi bahwa dari keseluruhan data pada kinerja NI yaitu sebanyak 12 sampel, nilai rata-rata (mean) yang diperoleh adalah sebesar ,06781606. Dari hasil uji nilai rata-rata ini diketahui bahwa dari 12 sampel data NI, terdapat 6 data yang berada di bawah nilai rata-rata, ketujuh nilai rata-rata ini berasal dari bank umum syariah tipe pemisahan murni maupun tipe pemisahan tidak murni.

\begin{tabular}{|rl|r|r|r|}
\hline \multicolumn{1}{|c|}{ Ranks } & \\
\hline Kinerja_NI & N & Mean Rank & Sum of Ranks \\
& Murni & 6 & 7,00 & 42,00 \\
& Tidak Murni & 6 & 6,00 & 36,00 \\
& Total & 12 & & \\
\hline
\end{tabular}

Sumber: hasil olahan SPSS

\section{Tabel 9. Hasil Uji Ranks Mann Whitney NI}

\section{Tipe Pemisahan Murni dan Tidak Murni}

Dari tabel 9 Ranks diatas, diperoleh informasi bahwa terdapat dua kelompok dengan tipe pemisahan yang berbeda. Pertama, bank umum syariah hasil pemisahan (Spin-Off) dengan tipe pemisahan murni. Kedua, bank umum syariah hasil pemisahan (Spin-Off) dengan tipe pemisahan tidak murni. Dari tabel ini juga menunjukkan Mean Rank atau ratarata NI tiap tipe pemisahan. Pada tipe murni rata-rata NI 7,00 lebih besar daripada rata-rata tipe tidak murni, yaitu 6,00. Dari hasil uji ini, dapat disimpulkan bahwa perbedaan rata-rata NI antara kedua tipe pemisahan hanya sebesar 1,00.

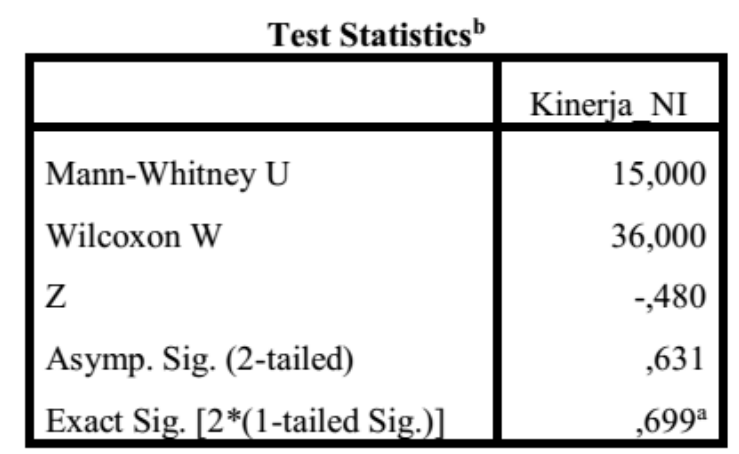

a. Not corrected for ties.

b. Grouping Variable: TIpe

Sumber: hasil olahan SPSS

Tabel 10. Hasil Uji Test Statistics Mann Whitney NI

Tipe Pemisahan Murni dan Tidak Murni 

Dari tabel 10 Test Statistics diatas. diperoleh informasi bahwa nilai Asymp. Sig. (2-tailed) yaitu 0,631 lebih besar dari 0,05. Hal ini menyatakan bahwa Ho diterima. Dengan ditolaknya $\mathrm{Ha}$ maka dapat disimpulkan bahwa tidak terdapat perbedaan NI secara signifikan antara tipe pemisahan murni dan tipe pemisahan tidak murni.

\section{Pembahasan Hasil Penelitian}

Spin-off atau pemisahan merupakan suatu tindakan yang dilakukan oleh suatu badan hukum Bank Umum Konvensional dalam usaha untuk merubah Unit Usaha Syariah yang dimiliki menjadi Bank Umum Syariah (BUS). Spin-off diyakini dapat mempercepat perkembangan perbankan syariah di Indonesia. Hal ini dikarenakan dengan dilakukannya spin-off maka memungkinkan bagi badan hukum baru untuk mengatur dan mengelola keuangan secara independen sehingga semakin fokus dalam beroperasi, cepat dan fleksibel dalam pengambilan keputusankeputusan bisnis, serta memungkinkan manajemen bebas mengambil kebijakankebijakan untuk pengembangan dan perbaikan bisnis dapat dilakukan lebih tepat guna.

Kebijakan ini mampu mengupayakan pengembangan perbankan syariah untuk menjadikan bank umum syariah yang lebih murni dalam menjalankan kegiatan operasinya berdasarkan prinsip syariah dengan pembatasan yang jelas antara unit usaha syariah dengan bank umum konvensional sehingga usaha syariah tidak tercampur dengan usaha bank umum konvensional yang dilarang dalam prinsip Islam. Dengan demikian bank umum syariah dapat leluasa menjalankan kebijakan yang telah dibentuk berdasarkan prinsip syariah.

Suatu badan hukum Ban Umum Konvensional (BUK) yang memiliki unit usaha syariah diwajibkan untuk memisahkan unit usaha syariahnya. Hal ini sesuai dengan ketentuan Undang Undang Nomor 21 tahun 2008 tentang perbankan syariah. Dalam undang-undang ini dinyatakan bahwa seluruh unit usaha syariah harus melakukan pemisahan (spinoff) dari induknya menjadi bank umum syariah maksimal 15 tahun setelah diterbitkannya undang-undang tahun 2008 tersebut. Hal ini juga dipertegas oleh Direktur Penelitian, Pengembangan, Pengaturan dan Perizinan Perbankan Syariah OJK Deden Firman yang menyatakan bahwa Otoritas Jasa Keuangan (OJK) memberikan batas waktu hingga akhir 2023 untuk setiap Unit Usaha Syariah yang ada di beberapa sistem perbankan di Indonesia untuk memisahkan diri.

Dalam hal spin-off unit usaha syariah menjadi bank umum syariah, Bank Indonesia mengeluarkan Peraturan Bank 
Indonesia (PBI) mengenai tipe pemisahan yang dapat dilakukan. Adapun tipe pemisahan tersebut yaitu tipe pemisahan murni dan tipe pemisahan tidak murni. Pemilihan tipe pemisahan ini harus mempertimbangkan berbagai faktor dan elemen karena setiap tipe pemisahan yang diambil memiliki konsekuensi kelebihan dan kekurangan masing-masing. Badan hukum harus mengetahui tipe mana yang mampu mewujudkan salah satu tujuan pemisahan (spin-off) yakni memperbaiki dan memaksimalkan laba perusahaan.

Menurut Prastowo dalam Ramadhan (2015) untuk menilai kinerja keuangan suatu perusahaan diperlukan ukuranukuran. Biasanya alat ukur yang digunakan berupa rasio keuangan. Rasio keuangan yang seringkali digunakan sebagai ukuran kinerja adalah yang berupa penghasilan bersih (laba) (Suwiknyo, 2010). Laba merupakan salah satu tujuan penting karena laba dapat mencerminkan kemampuan perbankan dalam melakukan produktivitas terhadap aset yang dimiliki. Dengan adanya penelitian yang berlandasakan pada laba (rentabilitas) ini, maka bank umum syariah dapat menunjukkan kondisi laba yang baik sehingga akan meningkatkan keputusan investasi para investor dan calon investor yang akan menanamkan modalnya pada perbankan. Kemampuan perbankan dalam menghasilkan laba dapat diukur menggunakan indikator dari beberapa rasio rentabilitas berdasarkan Surat Edaran Otoritas Jasa Keuangan (SEOJK) Nomor 10/SEOJK.03/2014 tentang Penilaian Tingkat Kesehatan Bank Umum Syariah dan Unit Usaha Syariah terdapat beberapa rasio rentabilitas yaitu rasio Return On Asset (ROA), Net Operating Margin (NOM) dan Net Imbalan (NI).

Penelitian ini akan membahas mengenai nilai laba yang tercermin dari rasio rentabilitas yaitu ROA, NOM dan NI. Dalam penelitian ini akan dibandingkan nilai laba yang dihasilkan oleh bank umum syariah hasil pemisahan (spin-off) selama 3 tahun setelah menjadi bank umum syariah. Dari hasil perbandingan akan terlihat manakah dari kedua tipe pemisahan yang mampu meningkatkan rentabilitas lebih baik bagi bank umum syariah hasil spin-off, sehingga hal ini akan menjadi salah satu acuan yang dapat dijadikan pertimbangan bagi bank umum konvensional yang harus memisahkan unit usaha syariahnya menjadi bank umum syariah maksimal pada akhir tahun 2023.

Sebelum membandingkan menggunakan uji beda Mann Whitney $U$ Test, peneliti melakukan pengukuran nilai rasio rentabilitas dari masing-masing tipe pemisahan yang ada terlebih dahulu. 
Ratna Maya Sari : Rentabilitas Bank Umum Syariah..

Berikut rangkuman hasil penelitian yang

telah dilakukan dalam penelitian ini:

\begin{tabular}{|c|c|c|l|}
\hline \multirow{2}{*}{$\begin{array}{c}\text { Rasio } \\
\text { Kinerja }\end{array}$} & \multicolumn{2}{|c|}{$\begin{array}{c}\text { Nilai Rata-rata Tipe } \\
\text { Pemisahan }\end{array}$} & \multirow{2}{*}{ Uji Beda } \\
\cline { 2 - 3 } & Murni & Tidak Murni & \\
\hline ROA & $0,79 \%$ & $-2,90 \%$ & Berbeda signifikan \\
\hline NOM & $4,89 \%$ & $4,40 \%$ & Tidak berbeda signifikan \\
\hline NI & $6,97 \%$ & $6,60 \%$ & Tidak berbeda signifikan \\
\hline
\end{tabular}

Sumber: hasil olahan SPSS

\section{Tabel 11. Hasil Penelitian}

Diketahui, rasio Return On Asset (ROA) merupakan rasio untuk mengukur seberapa besar persentase total aset mampu menghasilkan laba. Adapun nilai ROA ini berasal dari laba sebelum pajak dibagi dengan seluruh aset yang dimiliki perbankan yang bersangkutan. Semakin tinggi nilai aset yang dimiliki maka akan cenderung menghasilkan laba yang cukup tinggi sehingga persentase ROA akan semakin besar. Hasil penelitian menunjukkan bahwa terdapat perbedaan yang signifikan antara tipe pemisahan murni dan tipe pemisahan tidak murni. Tipe pemisahan murni mampu menghasilkan nilai rata-rata ROA lebih tinggi dibandingkan tipe pemisahan tidak murni.

Tipe pemisahan murni mampu menghasilkan rata-rata ROA sebesar 0,79\%. Nilai sebesar ini, jika dilihat berdasarkan ketentuan Bank Indonesia, berada pada peringkat 3 yang mencerminkan bahwa keberhasilan manajemen bank umum syariah tipe murni dalam menghasilkan laba tergolong cukup baik namun terdapat beberapa kelemahan yang dapat menyebabkan peringkat kompositnya memburuk apabila bank umum syariah tidak segera melakukan tindakan korektif. Sedangkan tipe pemisahan tidak murni menghasilkan ratarata ROA sebesar $-2,90 \%$. Nilai sebesar ini, jika dilihat berdasarkan ketentuan Bank Indonesia, berada pada peringkat 5 yang mencerminkan bahwa bank umum syariah sangat sensitif terhadap pengaruh negatif kondisi yang dapat membahayakan kelangsungan usaha.

Perbedaan yang sangat signifikan terjadi akibat besarnya biaya-biaya yang harus dikeluarkan oleh tipe pemisahan tidak murni. Besarnya biaya yang dikeluarkan ini mengakibatkan terjadinya kerugian pada tahun awal setelah menjadi bank umum syariah. Biaya yang paling mendominasi adalah biaya bunga yang masih harus ditanggung oleh bank umum syariah hasil spin-off tidak murni karena merupakan bank umum konvensional yang 
berbasis bunga sebelum melakukan konversi. Adapun salah satu faktor yang paling mendorong keberhasilan tipe pemisahan murni adalah keadaan budaya perbankan yang telah dimiliki tipe pemisahan murni. Budaya perbankan yang sudah terbentuk pada saat berstatus sebagai unit usaha tidak mengalami banyak perubahan setelah menjadi bank umum syariah, karena tidak adanya proses akuisisi yang dilakukan. Hal ini menjadi salah satu kelebihan yang dimiliki oleh tipe pemisahan murni karena dengan adanya budaya manajemen perbankan yang telah stabil mampu mendorong besarnya produktivitas total aset dalam menghasilkan laba.

Hasil dalam penelitian ini merupakan salah satu pembuktian empiris atas penelitian yang dilakukan Rizqullah dalam Arif (2014), Rahma D (2015), dan Rifin, dkk (2015) yang menyatakan bahwa ketika suatu UUS akan memutuskan untuk pemisahan (spin-0ff) dengan tipe pemisahan murni, ada beberapa elemen yang dapat mempengaruhi yakni: budaya perusahaan, program komunikasi, respon nasabah, delivery channel, respon pesaing, perpajakan, kepraktisan, infrastruktur dan rencana strategis. Sedangkan ketika suatu UUS akan memisahkan diri dengan tipe pemisahan kedua yaitu dengan menggunakan badan hukum yang sudah ada atau dengan cara akuisisi, konversi, dan merger maka elemen yang mempengaruhi ialah pengalihan status pegawai, sistem pelaporan dan pembukuan, sistem IT, perpajakan, respon regulator, due diligence, stakeholders concern, dan orientasi internal.

Selain itu, ada pula rasio Net Operating Margin (NOM) yang merupakan suatu rasio untuk mengukur seberapa besar total aktiva produktif mampu menghasilkan pendapatan dari penyaluran dana setelah dikurangi beban bagi hasil dan beban operasional. Hasil dalam penelitian ini menunjukkan bahwa tidak ada perbedaan yang signifikan antara tipe pemisahan murni dan tipe pemisahan tidak murni. Dapat dilihat bahwa nilai ratarata NOM yang dihasilkan kedua tipe pemisahan tidak berbanding jauh meskipun tipe pemisahan murni mampu menghasilkan nilai rata-rata yang sedikit lebih tinggi dibandingkan dengan tipe pemisahan tidak murni.

Kedua tipe mampu menghasilkan ratarata NOM lebih dari 3\%, yang jika dilihat berdasarkan ketentuan yang dikeluarkan Bank Indonesia berada pada peringkat 1 . Hal ini mencerminkan bahwa kemampuan aktiva produktif bank umum syariah dari masing-masing tipe dalam menghasilkan laba tergolong sangat baik. Begitupun halnya dengan penerapan prinsip 
Ratna Maya Sari : Rentabilitas Bank Umum Syariah..

akuntansi, pengakuan pendapatan, mampu menghasilkan nilai rata-rata yang pengakuan biaya dan pembagian keuntungan (profit sharing) telah dilakukan sesuai dengan ketentuan yang berlaku. Hasil penelitian pada NOM ini sesuai dengan penelitian yang dilakukan oleh Al Arif (2014) yang menyatakan bahwa setiap unit usaha syariah yang hendak melakukan pemisahan dapat memilih salah satu dari kedua tipe pemisahan tergantung kepada kebutuhan dari institusi bersangkutan. Al Arif (2014) melakukan penelitian mengenai pengaruh tipe pemisahan terhadap kinerja aset.

Adapun Rasio Net Imbalan (NI) merupakan rasio untuk mengukur tingkat efektivitas aktiva produktif dalam memperoleh pendapatan bersih dari penyaluran dana yang dihasilkan perbankan sebagai mudharib. Net Imbalan sejatinya sama dengan NOM, namun NI menggambarkan rentabilitas yang lebih konkrit karena rasio ini benar-benar melihat seberapa besar penyaluran dana/pembiayaan mampu menghasilkan pendapatan yang telah dikurangi beban imbal hasil. Maka dari itu, hasil uji yang ditunjukkan rasio ini juga sama seperti pada rasio NOM, bahwa tidak ada perbedaan yang signifikan antara tipe pemisahan murni dan tipe pemisahan tidak murni. Nilai rata-rata NI yang dihasilkan kedua tipe pemisahan juga tidak berbanding jauh. Tipe pemisahan murni sedikit lebih tinggi dibandingkan dengan tipe pemisahan tidak murni yaitu dengan selisih nilai rata-rata NOM sebesar $0,37 \%$.

Disini peneliti menggunakan dasar ketentuan Bank Indonesia pada NOM untuk diberlakukan sebagai dasar penentuan peringkat pada rasio Net Imbalan. Hal ini dikarenakan Bank Indonesia belum mengeluarkan ketentuan penetapan peringkat khusus untuk rasio NI. Dari hasil penelitian, kedua tipe mampu menghasilkan rata-rata NI masingmasing lebih dari 3\%, yang jika dilihat berdasarkan ketentuan penetapan peringkat berada pada peringkat 1. Hal ini mencerminkan bahwa kemampuan aktiva produktif bank umum syariah dari masingmasing tipe dalam menghasilkan pendapatan penyaluran bersih sebagai mudharib tergolong sangat baik. Dengan hal ini, dapat dinyatakan bahwa kemampuan rentabilitas bank umum syariah dalam mengantisipasi potensi kerugian dan meningkatkan modal sangat tinggi.

\section{SIMPULAN}

Hasil pengujian hipotesis pada rasio ROA menunjukkan bahwa terdapat perbedaan secara signifikan pada kinerja keuangan pada bank umum syariah tipe pemisahan murni (BNI Syariah dan BJB Syariah) dan tipe pemisahan tidak murni 
(BRI Syariah dan BUKOPIN Syariah). Tipe pemisahan murni mampu meningkat rentabilitas lebih baik daripada tipe pemisahan tidak murni. Namun hasil pengujian hipotesis pada rasio NOM dan NI menujukkan bahwa tidak terdapat perbedaan secara signifikan pada kinerja keuangan pada bank umum syariah tipe pemisahan murni maupun tipe pemisahan tidak murni.

Dari tiga rasio rentabilitas yang dijadikan variabel penelitian, dua diantaranya menyatakan bahwa tidak terdapat perbedaan yang signifikan antara masing-masing tipe pemisahan. Dengan demikian, dapat disimpulkan dari hasil penelitian ini bahwa baik tipe pemisahan murni (BNI Syariah dan BJB Syariah) maupun tipe pemisahan tidak murni (BRI Syariah dan BUKOPIN Syariah) memiliki kualitas yang sama dalam hal produktifitas terhadap aset yang dimiliki.

\section{DAFTAR PUSTAKA}

Arif, M. 2014. Tipe Pemisahan Dan Pengaruhnya Terhadap Nilai Aset Bank Umum Syariah Hasil Pemisahan. Tersedia: https://ojs.uajy.ac.id/index.php/kinerja /article/download/528/ 551. [Diakses 5 Juli 2017].
Mulya, P.B. (2011). Menghitung Rasio Likuiditas, Solvabilitas, Rentabilitas dan Perputaran Piutang PT COLORPAK INDONESIA, Tbk. Tersedia: https://pandubudimulya.wordpress.co m/2013/11/25/menghitung-rasiolikuiditassolvabilitas-rentabilitas-danperputaran-piutang-pt-colorpakindonesia-tbk/. [Diakses 11 Desember 2017].

Otoritas Jasa Keuangan.(2014). Statistik Perbankan Syariah 2014 [Online]. Tersedia : www.bi.go.id. [Diakses 30 September 2016].

Pernyataan Standar Akuntansi keuangan (PSAK) No. 101

Peraturan Bank Indonesia. 2009. PBI Nomor 11/10/PBI/2009 Tentang Unit Usaha Syariah. Tersedia: http://www.bi.go.id/id/peraturan/perba nkan/Documents/5cce3d74c8a443fcaa $\underline{2 \mathrm{e}}$

9dad54a22faaPBINo11_10_PBI_2009 penjelasan.pdf.

Rahma, Rifin dan Saptono. (2015). Pemilihan Metode Spin Off Unit Bisnis Syariah Dengan Pendekatan Analisa Faktor. Tersedia: repository.sb.ipb.ac.id/2302/5/E43-05RahmaPendahuluan.pdf. [Diakses 2 Januari 2017]. 
Ratna Maya Sari : Rentabilitas Bank Umum Syariah..

Ramadhan, R. (2015). Analisis

Pengukuran Kinerja Keuangan Dan

Kinerja Non Keuangan

Perbankan Syariah Di Indonesia. TA

yang tidak diterbitkan.

Republik Indonesia. 1998. Perubahan Atas

Undang-Undang Nomor 7 Tahun

1992

Tentang

Perbankan.

Tersedia:

http://hukum.unsrat.ac.id/uu/uu_10_9

$\underline{\text { 8.htm. }}$.

Republik Indonesia. 2008. Undang-

Undang Nomor 21 Tahun 2008

Tentang Perbankan

Syariah. Tersedia:

www.hukumonline.com.

Suwiknyo. (2010). Analisis Laporan

Keuangan Perbankan Syariah.

Yogyakarta: Pustaka

Pelajar 